\title{
分析試薬としての $\beta$-ジケトン
}

\section{千葉大学薬学部 山 根 靖 弘}

$\beta$-ジケトンとはアセチルアセトン $(2,4$-ペンタンジオ ン）のように一般に-CO-C $-\mathrm{CO}$ - 基をもつ化合物の総 称であり，1,3-ジケトンとも呼ばれている. 分析試薬と して用いられている $\beta$-ジケトンはすべて R-CO- $\mathrm{CH}_{2-}$ $\mathrm{CO}-\mathrm{R}^{\prime}$ 型（ $\mathrm{R}$ および $\mathrm{R}^{\prime}$ は有機残基を示す）のもので ある.

この $\beta$-ジケトンは種々の金属イオンと安定なキレー 卜化合物を生成する性質をもち, 金属の種類により着色 し, また有機溶媒に溶解しやすい性質をもっているので, 分析試薬として呈色反応, ペーパークロマトグラフ, 比 色定量, あるいは溶媒抽出に広く用いられている. さら に $\beta$-ジケトンと第一級アミンとが定量的に反応する性 質を利用して，第一級アミンの定量にも用いられてい る.

\section{$1 \beta$-ジケトンの性質}

$\beta$-ジケトンの一般的性質にふれてみよう. $\beta$-ジケト ンの活性メチレン基の水素は (1) 式のように転移してェ ノ一ル化合物を生じ,ケトーエノールの互変異性を示す. このエノールは弱い酸性を示すので，金属イオンと置換 され， $\beta$ 位のケトンの酸素の孤独電子対は金属に配位し て，いわゆる金属キレート化合物を生ずる.

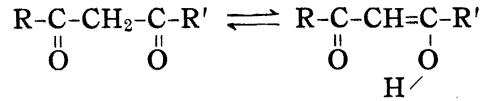

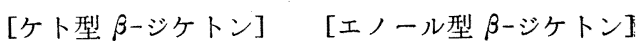
エノール型 $\beta$-ジケトン $+\mathrm{Me}^{n+}$<smiles>[R]C(=C[CH+]C)C=C([R])OC</smiles>

すなわち，(2) 式のように二重結合を二箇有する六員 環のキレート化合物を生ずる. $\beta$-ジケトンの $\mathrm{R}$ および $\mathrm{R}^{\prime}$ 学適当にかえることによって，金属キレート化合物 の性質を左右することができる. したがって分析の目的 によって多くの $\beta$-ジケトンが合成されているが，利用 されている主な $\beta$-ジケトンの構造と性質を Table 1 に まとめた。

防ケトンは一般に無色または淡黄色の液体または 結晶で, エーテル, アルコール, ベンゼンあるいは四塩 化炭素のような有機溶媒によく溶け, 水には難溶のもの が多い. 以下各種の $\beta$-ジケトンは Table 1 の略号で あらわす。

Table $1 \quad \beta$-ジケトンの性質

\begin{tabular}{|c|c|c|c|c|c|c|}
\hline \multirow{2}{*}{$\boldsymbol{\beta}$-ジケトン } & \multicolumn{2}{|c|}{ 構 造 } & \multirow{2}{*}{ 略 号 } & \multirow{2}{*}{\multicolumn{2}{|c|}{$\begin{array}{c}\text { 融点または沸点 } \\
\left({ }^{\circ} \mathrm{C}\right)\end{array}$}} & \multirow{2}{*}{$\mathrm{K}_{\mathrm{a}} \mathrm{p}$} \\
\hline & $\mathbf{R}$ & $\mathbf{R}^{\prime}$ & & & & \\
\hline アセチルアセトン & $-\mathrm{CH}_{3}$ & $-\mathrm{CH}_{3}$ & AA & $\mathrm{bp}$ & $133 \sim 5$ & 8.9 \\
\hline ベンゾイルアセトン & $-\mathrm{CH}_{3}$ & & B A & $\mathrm{mp}$ & $57 \sim 8$ & $9.8 \dagger$ \\
\hline ジベンゾイルメタン & & & D BM & $\mathrm{mp}$ & 78 & $10.3+t$ \\
\hline 2-フロイルベンゾイルメタン & & & F BM & $\mathrm{mp}$ & 69 & $9.5+t$ \\
\hline トリフルオロアセチルアセトン & $-\mathrm{CF}_{3}$ & $-\mathrm{CH}_{3}$ & TAA & bp & 107 & $6.9 \dagger$ \\
\hline 2-フロイル・トリフルオロアセトン & $-\mathrm{CF}_{3}$ & & FTA & $\mathrm{mp}$ & $19 \sim 21$ & $5.4 \dagger$ \\
\hline 2-テノイル・トリフルオロアセトン & $-\mathrm{CF}_{3}$ & & TTA & $\mathrm{mp}$ & 42.5 & $6.1 \dagger$ \\
\hline
\end{tabular}

† $50 \%$ シオキサン溶液, †† $75 \%$ ジオキサン溶液. 
2 呈色反応

\section{$2 \cdot 1$ 二硫化崖素1)2}

A Aのタリウム錯塩のアルコールあるいはベンゼン溶 液に二硫化炭素 1 滴を加えると, 微量の場合は黄色, 多 量の場合は橙色の沈殿を生ずる. この反応は二硫化炭素 に特異的でしかもかなり鋭敏であり, ベンゼン $1 l$ 中二 硫化炭素 $1 \mathrm{~g}$ の検出が可能である.

\section{$2 \cdot 2$ タリゥム 1}

上記 $2 \cdot 1$ の二硫化炭素の反応と同様の反応を行う. 特 異的であるが, 感度が低いのが欠点である.この沈殿の推 定構造式はつぎのとおりである。この呈色物は酸にもア

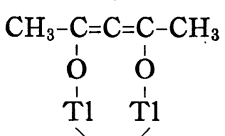
$\left(\mathrm{CS}_{2}\right)$ ルカリにも安定で, 分析の結 果 $\beta$-ジケトン 1 分子とタリ ウム 2 原子および二硫化炭素 1 分子を含えでいる.

\section{$2 \cdot 3$ ジルコニウムおよびハフニウム1}

$\mathrm{AA}$ の $\mathrm{Zr}$ あるいは Hf の錯塩 (無色) を二硫化炭素に 加えると赤色を呈する.

\section{$2 \cdot 4$ チタニウム ${ }^{3)}$}

$\beta$-ジケトンは $\mathrm{Ti}^{3+}$ 打よび $\mathrm{Ti}^{4+}$ と, 塩酸酸性溶液 で着色キレート化合物を生ずる. $\mathrm{Ti}^{3+}$ の場合は, $\mathrm{AA}$ は赤色であるが，BA，DBM および FBM などは青緑 色ないし緑色を呈する。 $\mathrm{Ti}^{4+}$ の場合は大体黄色ないし 橙色を呈する. $\mathrm{Ti}^{3+}$ に対しては $\mathrm{AA}$ および $\mathrm{BA}$ が感度 がよく 1 滴中 $1 \gamma, \mathrm{Ti}^{4+}$ に対しては FBM がもっとも感 度がよく，1滴中 $0.1 \gamma$ が検出できる．従来のクロモト ロプ酸や $\mathrm{H}_{2} \mathrm{O}_{2}$ 法よりも鋭敏である. $2 \mathrm{~N}$ 塭酸酸性で行 うと妨害イオンは少なく, $\mathrm{Fe}^{3+}, \mathrm{Zr}^{4+}$ および $\mathrm{F}$-が妨 害する程度であるが, $\mathrm{Fe}^{3+}$ は $\mathrm{Fe}^{2+}$ に還元し, $\mathrm{F}^{-}$は塩 化ベリリウムを加えることによりその妨害を除くことが できる.このチタンキレート化合物の組成は Ti : $\beta$-シ ケトン $=1: 3$ である.

\section{5 その他の金属)55}

$\beta$-ジケトンは特別の条件をあたえなければ，金属イオ ンに対して特異性はなく多くの金属とキレート化合物を つくる. しかし呈色の感度が高いことを利用して金属イ オンの予試験的検索に用いることができるＦTA につ いてその呈色,感度ならびに溶媒への抽出状態を Table 2 に示した。

なお $\mathrm{Hg}^{2+}, \mathrm{Pb}^{2+}, \mathrm{Zn}^{2+}, \mathrm{Cd}^{2+}, \mathrm{Be}^{2+}, \mathrm{Mg}^{2+}, \mathrm{Ca}^{2+}$,
Table 2

\begin{tabular}{|c|c|c|c|}
\hline Ion & Color & $\begin{array}{l}\text { Sensitivity } \\
\gamma / 0.1 \mathrm{ml}\end{array}$ & $\begin{array}{l}\text { Most useful extracting } \\
\text { solvent }\end{array}$ \\
\hline $\mathrm{Fe}^{2+}$ & Purple & 0.2 & $n$-Butanol \\
\hline $\mathrm{Fe}^{3+}$ & Red & 2 & Methyl-isopropyl ketone \\
\hline $\mathrm{Co}^{2+}$ & Yellow & 2 & " \\
\hline $\mathrm{Ni}^{2+}$ & Green & 2 & " \\
\hline $\mathrm{Cu}^{2+}$ & Green & 2 & " \\
\hline $\mathrm{Mn}^{2+}$ & Yellow & 2 & " \\
\hline $\mathrm{Ce}^{4+}$ & Brown & 1 & \\
\hline $\mathrm{Au}^{3+}$ & Blue-black & 1 & \\
\hline $\mathrm{Pd}^{2+}$ & Yellow & 5 & $n$-Butanol \\
\hline $\mathrm{Ti}^{4+}$ & Yellow & 1 & 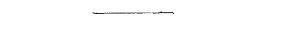 \\
\hline $\mathrm{UO}_{2}{ }^{2+}$ & Yellow & 1 & $n$-Butanol \\
\hline $\mathrm{Mg}^{2+}$ & Fluorescent & $<2$ & \\
\hline $\mathrm{Zr}^{4+}$ & $" \prime$ & 2 & -... \\
\hline $\mathrm{Al}^{3+}$ & $" \prime$ & 2 & $-1-$ \\
\hline $\mathrm{La}^{3+}$ & " & 2 & \\
\hline $\mathrm{Be}^{2+}$ & " & $<2$ & - \\
\hline
\end{tabular}

$\mathrm{Sr}^{2+}, \mathrm{Ba}^{2+}, \mathrm{Al}^{3+}, \mathrm{Ga}^{3+}, \mathrm{In}^{3+}, \mathrm{La}^{3+}, \mathrm{Th}^{4+}, \mathrm{Zr}^{4+}$ 注白色 沈殿を生ずるので，黒色の滴板（皿）を用いればよい。 その他アルカリ金属, $\mathrm{Ag}^{+}, \mathrm{Sb}^{3+}, \mathrm{Bi}^{3+}, \mathrm{Hg}_{2}{ }^{2+}, \mathrm{Sn}^{2+}$, $\mathrm{Tl}^{+}, \mathrm{CrO}_{4}{ }^{2-}, \mathrm{Cr}_{2} \mathrm{O}_{7}{ }^{2-}$ などは除性である.

3 金属イオンのペーパークロマトグラ.フ

$\beta$-ジケトンは種種の金属イオンと安定なキレート化合 物を生ずる性質があるので，金属イオンのペーパークロ マトグラフに用いられる. この場合展開溶媒中にキレー 卜生成試薬として $\beta$-ジケトンを溶解して用いる場合と, 金属キレート化合物を生成させ，乙れをスポットしてか ら溶媒で展開させる方法とがある.

\section{$3 \cdot 1$ AA を用いる場合}

\subsubsection{AA 含むブタノールによる展開6) ブタノ} ール中にキレート生成試薬である A A を溶かした液を 展開溶媒とし，金属イオンの水溶液を沪紙にスポットし て展開する。その主な Rf 值を Table 3 に記載した。 なおこのほか，ブタノールー $N$ 硝酸 $(1: 1) に 1 \%$ の割 合に A A を溶解した展開溶媒を用いて, 分離の困難で あった $\mathrm{K}, \mathrm{Ti}, \mathrm{V}, \mathrm{Mo}$ および $\mathrm{Fe}$ の分離に成功した。 そ の Rf 值は K 0.07，Ti 0.55, V 0.17，Mo 0.63 およ び $\mathrm{Fe} 0.40$ である. また水を飽和した $\mathrm{AA} 7.5 \mathrm{~m} l$ に 濃塩酸 $0.05 \mathrm{~m} l$ およびアセトン $2.5 \mathrm{~m} l$ を加えた溶媒》で 展開すると $\mathrm{Sn}^{2+}, \mathrm{Sb}^{3+}$ および $\mathrm{As}^{3+}$ を分離できる。 そ の Rf 值は Sn 1.0; Sb 0.5, As 0.2 である.

3.1.2 AAの金属キレート化合物の展開8) $\mathrm{Co}^{3+}$ ， $\mathrm{Cu}^{2+}$ および $\mathrm{Ni}^{2+}$ 対照としている. これらの $\mathrm{AA} の$ キレート化合物をスポットして,シクロヘキサン $(84 \%)$, 
ジオキサン $(10 \%)$ およびメタノール (6\%) の混合溶媒 で展開することにより良好な分離ができる，Rf 值の平 均值は \pm 0.02 の再現性がある. その位置は, Co は AA 塩の緑色およびジチオオキザミドのスプレイによる橙色 によって, Ni はジメチルグリオキシムと $\mathrm{NH}_{3}$ ガス, $\mathrm{Cu}$ はジチオオキザミドと $\mathrm{NH}_{3}$ ガスにより決定される. そ れぞれの Rf 值はCo 0.64, Cu 0.27, Ni 0.00 である.

\section{$3 \cdot 2$ BA を用(る場合(69) 11)}

BA をブタノールに溶解したものを展開溶媒として行 う.この場合適当な前处理をほどこして BA 含有のブタ ノールで展開して分離する方法と, 前処理（分離）せ ずにブタノール（含 BA）、コリジンー水拉よびアンチピ リン含有のジオキサンの三種類の展開溶媒を適当に組合 わせて分離定性する方法とがある. これらの Rf 值を Table 3 に示した.

まず, ブタノール（含 BA）のみで展開する場合の一 例を示すと, 検液( $\mathrm{a}$ ): 試料 $0.1 \mathrm{~g}$ を $2 N$ 硝酸 $2 \mathrm{~m} l$ と 劣沸する. 検液( $\mathrm{b}$ ) : 試料 $0.1 \mathrm{~g}$ を $2 N$ 塩酸 $2 \mathrm{~m} l$ と煮 沸する. 検液(c)：10\% NaOH の少過剩で処理する. これらの検液を用いてグループ別にしてクロマトグラフ を行う.
A群 : (i) $\mathrm{Ag}, \mathrm{Pb}, \mathrm{Hg}, \mathrm{Tl}$
(ii) $\mathrm{As}, \mathrm{Sb}$
B群 : (i) $\mathrm{Cr}, \mathrm{Ce}, \mathrm{Mn}, \mathrm{Co}, \mathrm{Cu}, \mathrm{Ni}$
(ii) $\mathrm{Bi}, \mathrm{Fe}, \mathrm{Ti}, \mathrm{V}$
C群 : (i) $\mathrm{Sn}, \mathrm{Sr}, \mathrm{Ba}$
(ii) $\mathrm{Cd}, \mathrm{Zn}, \mathrm{Al}, \mathrm{Mg}, \mathrm{Ca}$
D群 : Li, Na, K
E群 : Mo, W, V

検液 ( a ) は $\mathrm{A}$ 群, 検液 ( b ) は B, C および D群, 検液 （c）はE群の検出を行う．展開された金属の検出には塩 酸をスプレイして金属を遊離させてから，特異的または 選択的試薬を用いる. またコージ酸と8ヒドロキシキ, リンの混合試薬を用い，フルオレッセンスを検すること により，大多数の金属イオンを定性することができ，硫 化水素を用いる方法よりも優れている.

ついで三種の展開溶媒を用いる例を示す.

二方向, 三種溶媒による分離 : $\mathrm{Al}, \mathrm{Bi}, \mathrm{Mg}, \mathrm{Mn}, \mathrm{Cd}$ お よび $\mathrm{Cu}$ の分離を目的とした場合であるが，最初コリシ ン, ついでブタノール（含 BA）で異方向に展開する. ついで後者と同方向に ジオキサンで展開する. すなわ ち, はじめの二つの溶媒では $\mathrm{Bi}$ と $\mathrm{A} 1$ とは分離しない が，第三の溶媒ジオキサンは $\mathrm{Bi}$ と $\mathrm{Al}$ を分離させ， $\mathrm{Mg}, \mathrm{Mn}$ および Cd は新しい位置に移動し, 全部を分 離することができる.

\section{E3.3 DBM を用いる場合6)}

DBM をキレート生成試薬としてブタノールに溶解し
たものを展開溶媒に用いて, ペーパークロマトグラフに よる金属の分離も可能である. その Rf 值を Table 3 に示した.

Table 3 Rf values

\begin{tabular}{|c|c|c|c|c|c|}
\hline \multirow{2}{*}{ Metal } & \multicolumn{3}{|c|}{ Butanol containing } & \multirow{2}{*}{$\begin{array}{l}\text { Dioxane } \\
\text { containing } \\
\text { antipyrin }\end{array}$} & \multirow{2}{*}{ Collidine } \\
\hline & DBM & $\mathbf{B A}$ & AA & & \\
\hline $\mathbf{A g}$ & 0.18 & 0.10 & 0.15 & 0.08 & 0.78 \\
\hline $\mathrm{Hg}^{+}$ & 0.23 & 0.24 & 0.43 & 0.43 & 0 \\
\hline $\mathrm{Pb}$ & 0.11 & 0.03 & 0.09 & 0.15 & $\theta$ \\
\hline $\mathbf{H g}^{2+}$ & 0.23 & 0.31 & 0.43 & 0.42 & 0 \\
\hline $\mathbf{B i}$ & 0.15 & 0.02 & 0.23 & 0.63 & 0 \\
\hline $\mathrm{Cu}$ & 0.13 & 0.22 & 0.12 & 0.24 & 0.76 \\
\hline Cd & 0.13 & 0.05 & 0.12 & 0.18 & 0.76 \\
\hline As & 0.42 & 0.43 & 0.43 & 0.18 & 0.65 \\
\hline $\mathrm{Sb}$ & 0 & 0 & 0.02 & 0.65 & 0.38 \\
\hline $\mathrm{Sn}^{2+}$ & 0.73 & 0.58 & 0.82 & 0.77 & 0 \\
\hline $\mathrm{Sn}^{4+}$ & 0.65 & 0.55 & 0.81 & 0.58 & 0 \\
\hline $\mathrm{Al}$ & 0.13 & 0.03 & 0.09 & 0.03 & 0 \\
\hline $\mathrm{Cr}$ & 0.13 & 0.03 & 0.09 & 0.01 & 0 \\
\hline $\mathrm{Fe}^{3+}$ & 0.20 & 0.95 & 0.43 & 0.10 & 0 \\
\hline $\mathrm{Zn}$ & 0.14 & 0.05 & 0.10 & 0.08 & 0.75 \\
\hline Mn & 0.16 & 0.07 & 0.11 & 0.09 & 0.71 \\
\hline Co & 0.13 & 0.06 & 0.10 & 0.05 & 0.74 \\
\hline $\mathrm{Ni}$ & 0.13 & 0.03 & 0.09 & 0.05 & 0.76 \\
\hline $\mathbf{C a}$ & 0.11 & 0.05 & 0.08 & 0.10 & 0.52 \\
\hline $\mathrm{Sr}$ & 0.08 & 0.04 & 0.07 & 0.04 & 0.40 \\
\hline $\mathrm{Ba}$ & 0.06 & 0.02 & 0.09 & 0.02 & 0.26 \\
\hline $\mathbf{M g}$ & 0.11 & 0.06 & 0.10 & 0.04 & 0.65 \\
\hline $\mathbf{K}$ & 0.10 & 0.05 & 0.10 & 0.03 & 0.32 \\
\hline $\mathrm{Na}$ & 0.10 & 0.06 & 0.10 & 0.04 & 0.42 \\
\hline
\end{tabular}

\subsection{FTA を用いる場合4)}

FTA の金属キレート化合物をベンゼンーメタノーシ (98:2) の混合溶媒で展開する，分離定性できる金属は $\mathrm{Fe}, \mathrm{Cu}, \mathrm{Ni}, \mathrm{Co}$ おび $\mathrm{Mn}$ である. それらの Rf 值 は $\mathrm{Fe} 1.0, \mathrm{Cu} 1.0, \mathrm{Ni} 0.90, \mathrm{Mn} 0.28$, Co 0.00 で ある. $\mathrm{Fe}$ と $\mathrm{Cu}$ の分離は不可能であるが, 呈色試薬を 使いわけて定性することができる.

\subsection{TTA を用(る場合12)13)}

TTA の金属キレ゙ート化合物をベンゼンーメタノール および酢酸の混合溶媒で展開する.この際沪紙のみの場 合のほか, $\mathrm{NaCl}, \mathrm{Al}_{2} \mathrm{O}_{3}, \mathrm{SiO}_{2}$ あるいは殿粉を沪紙に しみこませたものを用いて展開を行っている. それらの 主なものについて Table 4 に示した.

Table 4 T T A キレート化合物の Rf 值

\begin{tabular}{llllllll}
\hline ベンゼンーメタノール-酢酸 & 型 & $\mathrm{Fe}$ & $\mathrm{Co}$ & $\mathrm{Ni}$ & $\mathrm{Mn}$ & $\mathrm{Cu}$ \\
\hline (A) $\quad 95: 5: 0$ & plain & 0.98 & 0.04 & 0.94 & 0.00 & 0.98 \\
(B) $88: 10: 2$ & $\mathrm{NaCl} \dagger$ & 0.99 & 0.11 & 0.29 & 0.00 & 0.95 \\
(C) & $68: 30: 2$ & $\mathrm{Al}_{2} \mathrm{O}_{3} \dagger$ & 0.95 & 0.53 & 0.90 & 0.49 & 0.93 \\
\hline † 沪紙に $\mathrm{NaCl}$ & または & $\mathrm{Al}_{2} \mathrm{O}_{3}$ & をしみこませたすの.
\end{tabular}


混合溶媒（A）は plain 型が分離能よく, $\mathrm{Fe}, \mathrm{Ni}, \mathrm{Co}$, $\mathrm{Cu}, \mathrm{Ni}, \mathrm{Co} ; \mathrm{Fe}, \mathrm{Ni}, \mathrm{Mn} ; \mathrm{Cu}, \mathrm{Ni}, \mathrm{Mn}$ が分離でき, 溶 媒 (B) は $\mathrm{Al}_{2} \mathrm{O}_{3}$ 型が分離能よく, $\mathrm{Cu}, \mathrm{Ni}, \mathrm{Co} ; \mathrm{Co}, \mathrm{Ni}$, $\mathrm{Mn} ; \mathrm{Fe}, \mathrm{Ni}, \mathrm{Mn} ; \mathrm{Fe}, \mathrm{Ni}, \mathrm{Co}$ の分離ができ, 溶媒 (C) は $\mathrm{NaCl}$ 型がよく, $\mathrm{Fe}, \mathrm{Co}, \mathrm{Ni} ; \mathrm{Fe}, \mathrm{Ni}, \mathrm{Mn} ; \mathrm{Cu}, \mathrm{Ni}$, $\mathrm{Mn}$ が分離できるが，いずれの場合も $\mathrm{Fe}$ と $\mathrm{Cu}$ 法分離 が不能である.一般に汇紙に吸着剂をしみこませると， ペーパーのみよりキレート化合物の移動率を低下させ る. 混合溶媒中にメタノールの含量が多くなると Rf 值 が大きくなる傾向がある.

$3.62-$-テイルパーフルオロブチリルメタン(TFBM) および2-フロイルパーフルオロブチリルメタン(FFBM) を用いる場合5)

$\mathrm{Fe}^{3+}, \mathrm{Co}^{2+}, \mathrm{Ni}^{2+}, \mathrm{Cu}^{2+}$ および $\mathrm{Mn}^{2+}$ のこれらのキ レート化合物を石油エーテル B-メタノールの混合溶媒 で効果的に分離した. 石油エーテルのみでは $\mathrm{Fe}^{3+} キ レ$ 一ト化合物は溶媒の先端付近, $\mathrm{Cu}$ は中程まで, $\mathrm{Ni}, \mathrm{Co}$ および Mn は移動しない.メタノールは Mnを除いて 全部溶媒の先端まで移動する. この両溶媒を用いて成功 したのである. TFBM の場合は石油エーテルーメタうー ル(92:8), FFBM の場合は石油エーテルーメタノールジオキサン (92: $7: 1)$ の混合溶媒が分離能良好である. これらの Rf 值を Table 5 に示した.

Table 5 Rf 值

\begin{tabular}{cccccc}
\hline キレート試薬 & $\mathrm{Fe}$ & $\mathrm{Cu}$ & $\mathrm{Ni}$ & $\mathrm{Co}$ & $\mathrm{Mn}$ \\
\hline T F BM & 0.82 & 0.77 & 0.51 & 0.47 & 0.35 \\
F F BM & 0.84 & 0.77 & 0.50 & 0.46 & 0.20 \\
\hline
\end{tabular}

さきの $\mathrm{AA}$ および BA では $\mathrm{Co}, \mathrm{Ni}, \mathrm{Mn}$ の分離が思わ しくなかったが, FTA, TTA, TFBM あるいは FFBM でその分離が容易となった. しかし TTAおよび FTA では $\mathrm{Fe}$ と $\mathrm{Cu}$ との分離ができなかったが, TFBM あ るいは FFBM で $\mathrm{Fe}$ と $\mathrm{Cu}$ との分離に良好な結果を おさめた.

\section{4 比色定量}

$\beta$-ジケトンの鉄, ウラニルおよびベリリウムのキレー 卜化合物は強い吸収を示すので，これらの金属を $\beta$-シ ケトンを用いて比色定量することができる. とくに近 時, ウラニルに対して $\beta$-ジケトンが非常に感度が高い ことが見出されてから，つぎつぎと新しい $\beta$-ジケトン が発表されている.

ここでは $\mathrm{Fe}^{3+}$ の定量とその退色を利用する $\mathrm{F}^{-}$の定
量および $\mathrm{UO}_{2}{ }^{2+}$ の定量について述べてみよう.

\section{$4 \cdot 1$ 鉄イオンの比色定量 (AA による方法) ${ }^{1) 1415)}$}

第二鉄イオン $\left(\mathrm{Fe}^{3+}\right)$ 汇 $\mathrm{AA}$ と赤色の安定なキレート 化合物を生じ，その呈色感度が非常に高いために，A A で $\mathrm{Fe}^{3+}$ を比色定量することができる. 0.5\%の A A ア ルコール溶液（また注水溶液）を用いる. $3 \gamma$ 程度の微 量まで定量ができ，チオシアン酸法の $6 r$ に対して高い 感度を有している．また後者の方法よりる広い範囲で定 量できる利点ももっている( $0.6 \mathrm{mg} \mathrm{Fe}$ まで定量可能). A A による方法はチオシアン酸法の適用できる範囲のる のはすべて行いうる.ただし $\mathrm{pH}$ の変化に対して呈色が 鋭敏に变化するので，その調節には注意を要する：希薄 溶液であれば他の金属イオンの妨害は少ない。また温度 の变化も影響をあたえない。

\section{$4 \cdot 2$ フッ素イオンの比色定量 ${ }^{16) 17)}$}

$\mathrm{AA}$ の $\mathrm{Fe}^{3+}$ キレート化合物のフッ素イオンによる脱 色儿基く比色定量である. その方法を略記すれば，つぎ のとおりである. $25 \mathrm{~m} l$ の各定容フラスコに $\mathrm{FeCl}_{3} 1$ $\mathrm{m} l$ と A A 溶液 $1 \mathrm{~m} l$ を加え, この一方のフラスコに $0.25 \mathrm{mg}$ 以下のフッ素を含む未知溶液を加えて, それぞ れを一定容に水で希釈して比色する. 本法はチオシアン 酸法より硫酸塩, 塩化物などによる影響が少ない。 \pm 0.1 ppm の正確性を有する.

\section{$4 \cdot 3$ ウラニルイオンの比色定量}

従来ウラニルイオンの比色定量法として過酸化水素 法, チオシアン酸アンモニウム法およびジェチルジチオ カルバミン酸法などが一般的に行わ机てきたが, 1953 年 に Joe らはジベンゾイルメタン (DBM) 法が前者の比 色定量法よりもかなり優れた感度を有することをみいだ し，その後各種の $\beta$-ジケトンが用いられるようになっ た.

4.3.1 DBM による方法 ウラニルとDBM のキ レート化合物の吸収の極大は $395 \mathrm{~m} \mu$ にあり, その組成<smiles>O=C1OC(c2ccccc2)=CC(c2ccccc2)O1</smiles>
は DBM : $\mathrm{UO}_{2}=2: 1$ である. Joe らの方 法18は $50 \%$ アルコ ール溶液で行い, 最適 $\mathrm{pH}$ は 6.5 8.5 で, $1 \mathrm{~cm}$ のセルを 用いたときのウラニウムの感度は $0.05 \mathrm{ppm}$ である. 他の金属の妨害をのぞくために, 硝酸酸性溶液に硝酸ア ンモニウムを加えて, 硝酸ウラニルをエーテルで抽出し 
ている.

その後 1958 年に Francois ${ }^{19)}$ は硝酸アルミニウム を含むウラニルイオン溶液からイソオクタン中のトリブ チルホスフェイトでウラニルを抽出し，この抽出液を DBM，ピリジンおよびアセトン一水の混合液(発色液)に 加えて呈色させ，生じたウラニルキレート化合物を 410 $\mathrm{m} \mu$ て測定を行っている. 操作が簡単で, しかもピリシ ンの緩衝作用のため $\mathrm{pH}$ の調節（pH=5.0〜 5.5）が容 易である利点をもっている. 一般の金属イオンおよびウ ラニルイオンの 10 倍までのトリウムは妨害しない. 0.05 0.50 mg U に抢いて定量ができ，誤差は $2 \%$ 以内, その分析に要する時間は螢光法とほとえど同じで ある。

\section{4·3·2２-アセトアセチルピリジンによる方法 ${ }^{20)}$}

ウラニルイオンを 2-アセトアセチルピリジン (AAP) によって比色定量する方法を原が報告している. $\mathrm{pH}=$ 7.0〜7.7 において酷酸ブチル中に AAP を溶解した液 を用いて抽出し，その抽出液を $382.5 \mathrm{~m} \mu$ で比色する. 前の DBM 法にくらべ優れた感度を有する. 精度は土 1\%である. なお感度はよいが，他の金属イオンの妨害 を受けやすいので，カラムエクストラクションにより， ウランの分離を行ったのち, 比色定量を行う.

\subsubsection{FBM による方法21）著者はつぎのような} $\beta$-ジケトンを用いてウラニルイオンの比色定量の検討を 行った. すなわち, BA, DBM, FBM, イソニコチニル

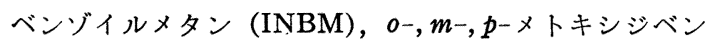
ゾイルメタン $(o-, m-, p-\mathrm{MDBM})$ を用いた。 この検 討の結果, 従来の DBM 法より感度のよいものとして FBM， $p$-MDBM および INBM を見出したが，そのう ちで FBM が最高の感度を有する. FBM のウラニルキ レート化合物の吸収極大は $404 \mathrm{~m} \mu$ にあり, 最適 $\mathrm{pH}$ は 5.6〜7.6である. $50 \%$ アルコール溶液で行い，0１20 $\gamma / 10 \mathrm{~m} l \mathrm{UO}_{2}$ に沶いて直線関係を示す. 吸収曲線と検 量線をとれぞれ Fig. 1 および Fig. 2 に示す.

\section{5 金属イオンの溶媒抽出}

金属イオンがキレート試薬と金属キレート化合物を生 ずると，一般に水に難溶性の沈殿となるが，有機溶媒に 溶けるものが多い。この場合金属イオンの水溶液と水に 混合しない有機溶媒にキレート試薬を溶かした液とをふ りまぜると，金属イオンはキレート化合物を生成して有 機溶媒層に移る．この方法が金属イオンの溶媒抽出の主 な例である．抽出能はキレート試薬の構造（性質）をは じめとして $\mathrm{pH}$, 溶媒, 試薬の濃度および抽出時間など に影響される。

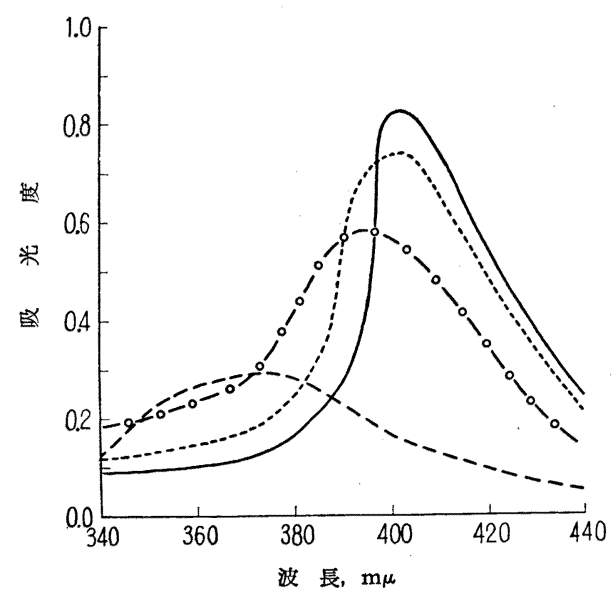

Fig. 1 忣収スペクトル
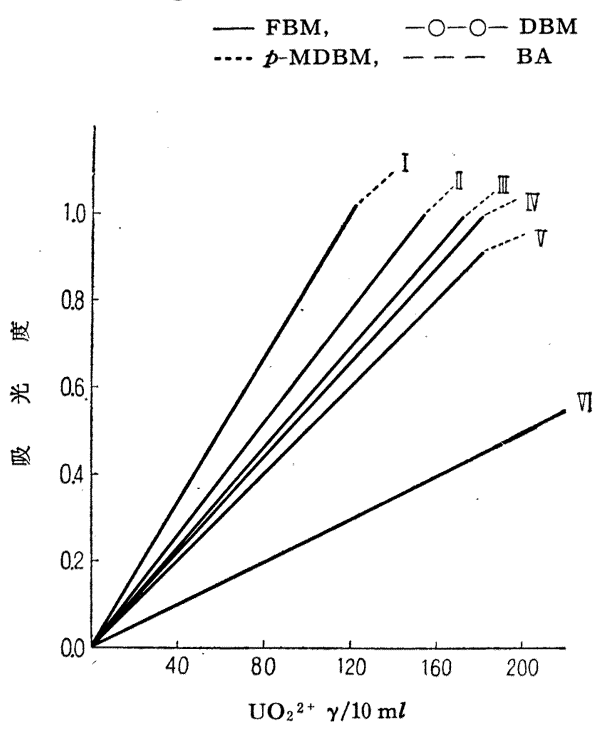

Fig. 2 検 量 線

\begin{tabular}{|c|c|c|c|}
\hline & & & \\
\hline & & $\begin{array}{l}\text { If } m \text {-MDBM } \\
\mathrm{V}: \mathrm{BA}\end{array}$ & $\begin{array}{l}(400 \mathrm{~m} \mu) \\
(375 \mathrm{~m} \mu)\end{array}$ \\
\hline
\end{tabular}

これらの溶媒抽出は, 従来オキシンのクロロホルム溶 液, ジチゾンのクロロホルム（または四塩化炭素）溶液 またはクッペロンのクロロホルム（または酶酸エチル） 溶液などによって行われてきたが，最近 $\beta$-ジケトンも 抽出試薬として重要な地位を占めてきた.

$\beta$-ジヶトンは先に述べたように一般に安定な六員環の 金属キレート化合物を生ずるが，これはベンゼン，キシ レンエーテルまたはクロロホルムによく溶ける。また （1）式の $\mathrm{R}, \mathrm{R}^{\prime}$ を適当な基敒置換すると溶解度， $\mathrm{pK}_{\mathrm{a}}$ またはキレート化合物の安定度などが変化して, 抽出能 
に影響をあたえる. 近時 $\mathrm{CH}_{3}$ 基のかわりに $\mathrm{CF}_{3}$ 基を 含有する $\beta$-ジケトンが合成された. このようにフッ素 のような強い陰性基を導入すると, キレート試薬の $\mathrm{pK}_{\mathrm{a}}$ は小さくなり(酸性度が強くなる), 金属イオンを強い酸 性でも抽出できるようになる。たとえば，中性または弱 酸性で加水分解を起す $\mathrm{Zr}$ や Th の上うな金属を, 強 い酸性溶液から抽出することができるという利点をもっ ている. また化学的に分離の困難な $\mathrm{Zr}$ と Hf を充分分 離できるようになった。このような理由で現今では，金 属の抽出に重要な地位を占めるにいたったのである.な お, これらの溶媒抽出はただ分析化学の分野のみに止ま らず，工業的にも金属の精製などに用いられ，イオン交 換やクロマトグラフと同様に重要な分離精製法の一つで ある.つぎに溶媒抽出に多く用いられているAAとTTA を溶媒抽出の立場からふれてみよう。

\section{$5 \cdot 1$ アセチルアセトン（AA)}

$\mathrm{AA}$ 法もっとも普通の $\beta$-ジケトンであり, 抽出には よく利用されている。これは無色の液体で水には $100 \mathrm{~g}$ 中 $17 \mathrm{~g}$ 程度溶ける. この水への比較的大きな溶解性は, 水層中の A A の濃度を高めるため，今まで可能であっ たよりもさらに強い酸性で抽出を行うことができ，また 抽出操作において平衡の達成に 要する時間が 短縮され る.さらに，低濃度の抽出ばかりでなくマクロの抽出も 可能である.

AA はキレート試薬としてばかりでなく，それ自身抽 出溶媒ともなりうる．として金属 $\mathrm{AA}$ キレート化合物 を他の溶媒より非常によく溶解する性質をもっている. また低価格であるため利用度も多い。

\section{2 テノイルトリフルオロアセトン (TTA)}

Reid および Calvin によって 1957 年に始めて紹介 されたが，これは核分裂物質や希土類などの分離・精製 に広く用いられている. この TTAの特徵は, 比較的強 、酸性でとくに安定であり，容易に多くの金属と安定な キレート化合物をつくることである．また中性あるいは 酸性溶液で金属キレート化合物が水に不溶であること, 高度の真空では容易に昇華するが，普通の条件では蒸発 しない（AAの金属キレート化合物は揮発性をむったも のが少なくない）ことなどの利点をもっている.

\section{$5 \cdot 3$ 溶媒抽出の応用}

溶媒抽出による金属の分離法について二，三述べてみ よう.

5.3.1 アクチニウムおよびトリゥムの抽出分離 ${ }^{22}$
種種の金属イオンを $0.25 M$ の TTA のベンゼン溶液 で抽出した場合の抽出曲線を Fig. 3 に示した. これに よると Ac は $\mathrm{pH}=5.5 \sim 6$ で完全に抽出され, 従来分 離精製の困難であった $\mathrm{Ra}$ と完全に分離することができ る.なおべンゼン層中の Ac 注 $6 N$ 塩酸で再抽出され る.

また Th は $0.1 N$ 塭酸酸性溶液から TTA により完 全に抽出され，これも他の金属イオンとの分離が可能で ある。

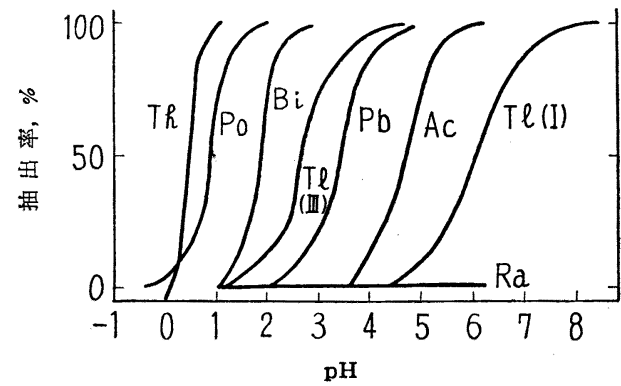

Fig. 3 抽出曲 線

5.3.2 ジルコニウムとハフニウムの抽出分離 $\mathrm{Zr}$ とHf は化学的に非常に類似した性質を有しているの で，それらの分離精製は，きわめて困難である。しかし TTA あるいは TAA を用いれば抽出分離することがで きる.

TTAを用いる分離法の一例をあげてみよう23)０.025 $M$ TTA のベンゼン溶液で $\mathrm{Hf}(22.9 \mathrm{mg})$ および $\mathrm{Zr}$ $(13.6 \mathrm{mg})$ 含有の $2 M$ 過塩素酸溶液を 2 回抽出すると, 水層には Hf が $6.31 \mathrm{mg}(27 \%)$ 存在し, $\mathrm{Zr}$ 以水層に はほとえど存在せず，1\% 以内である。

TAAを用いる場合には24)，TAA のベンゼン溶液に より, $0.2 N$ 塩酸酸性の $\mathrm{Zr}$ と $\mathrm{Hf}$ の混合溶液より両者 を分離することができる．Hf の精製は $\mathrm{Zr}$ をできるだ け少ない回数で抽出することが望ましく，このためべン ゼン層中に高濃度の $\beta$-ジケトンが必要である. $Z \mathrm{r}$ はベ ンゼン層中に濃縮されるので，つぎの抽出に先立ち，べ ンゼン層から $4.8 N$ 塩酸で水層にもどし，これをふたた び抽出する.たと光ば， Hf 約 $1.5 \%$ 含有の $\mathrm{Zr}$ - Hf 混 合溶液を 2 回抽出することにより，Hf を $0.09 \sim 0.1 \%$ にするととができる，Zr の収率は 5〜7\% である.

5.3.3 モリブデンの抽出分離25) 鉄鋼中の Mo の 抽出に AA が選択的抽出試薬として用いられる。 Mo (II) 6 . 6 硫酸溶液から A A のクロロホルム溶液 (1:1) 
Table 6 金属の溶媒抽出

\begin{tabular}{|c|c|c|c|c|c|}
\hline 金属 & 抽出試藥 & 抽出溶媒 & 性 & 考 & 交 献 \\
\hline Ac & TTA & Benzene & $\mathrm{pH}=5.5 \sim 6$ & $\mathrm{Ra}$ から分離, $6 N \mathrm{HCl}$ 再抽出 & 22) \\
\hline $\mathbf{A 1}$ & TTA & Benzene & $\mathrm{pH} \fallingdotseq 5.5$ & 濃 $\mathrm{HCl}$ 再抽出 & 26) \\
\hline$"$ & $\mathbf{A} \mathbf{A}$ & AA & $\mathrm{pH}=0$ & & 27) \\
\hline $\mathrm{Be}$ & $\mathbf{A A}$ & Benzene & $\mathrm{pH}=4 \sim 5$ & $5 N \mathrm{HCl}$ 再抽出 & 28) \\
\hline$" 1$ & TTA & Benzene & $\mathrm{pH} \doteqdot 7$ & $\mathrm{Al}$ 加ら分雞, 濃 $\mathrm{HCl} 80 \mathrm{hrs}$ 再抽出 & 26) \\
\hline $\mathrm{Ce}^{4+}$ & TTA & Xylene & $N \mathrm{H}_{2} \mathrm{SO}_{4}$ & 抽出時 $\mathrm{K}_{2} \mathrm{Cr}_{2} \mathrm{O}_{7}+\mathrm{NaBrO}_{3}$ を加元る & 29) \\
\hline $\mathrm{Cu}^{2+}$ & TTA & Benzene & $\mathrm{pH}=3.4$ & 濃 $\mathrm{HCl} 15 \mathrm{~min}$ 再抽出 & 26) \\
\hline$" \prime$ & AA & AA & $\mathrm{pH}=2.1$ & 抽出時 $\mathrm{H}_{2} \mathrm{SO}_{4}$ 酸性, $\mathrm{Zn}$ との分離 & 47) \\
\hline $\mathrm{Fe}^{3+}$ & TTA & Benzene & $\mathrm{pH} \doteqdot 2 \sim 3$ & 濃 $\mathrm{HCl} 15 \mathrm{~min}$ 再抽出 & 26) \\
\hline$"$ & A A & AA & $N$-acid & & 27) \\
\hline $\mathbf{G a}$ & AA & AA & $\mathrm{pH}=3$ & 定量的でない, $\mathrm{Al}$ も一緒に抽出 & 27) \\
\hline In & A A & A A & $\mathrm{pH}>3$ & 定量的, $\mathrm{Al}, \mathrm{Ga}$ 万一緒们抽出 & 27) \\
\hline Mo & TTA & Chloroform & $6 \mathrm{~N} \mathrm{H}_{2} \mathrm{SO}_{4}$ & $\mathrm{~W}, \mathrm{Cr}$ から分雄 & 25) \\
\hline Np & TTA & Benzene & $0.2 M \mathrm{HClO}_{4}$ & + & 30) \\
\hline$" 1$ & TTA & Xylene & $1 M \mathrm{HCl}$ & $\mathrm{Am}, \mathrm{Cm}$ から分離 & 31) \\
\hline $\mathbf{P u}$ & TTA & Xylene & $1 N \mathrm{HNO}_{3}$ & $\mathrm{U} ょ り$ 分離 & 32) \\
\hline Rare earth & TTA & Xylene & $\mathrm{pH}=4.5$ & Thより分離 & $33)$ \\
\hline $\mathrm{Th}$ & TTA & Benzene & $\mathrm{pH}=2.5\left(\mathrm{HNO}_{3}\right)$ & $2 \mathrm{~N} \mathrm{HNO}_{3}$ 再抽出 & 34) \\
\hline$" 1$ & TTA & Benzene & $0.2 \mathrm{~N} \mathrm{HNO}_{3}$ & 同上 & 35) \\
\hline$"$ & TTA & Benzenè & $\mathrm{pH}=2$ & $\begin{array}{l}6 N \mathrm{HCl} \text { 再抽出, } \mathrm{Ti} \text { は部分的に抽出 } \\
\mathrm{Al}, \mathrm{Ni}, \mathrm{Cr} \text { は抽出されない }\end{array}$ & $36)$ \\
\hline $\begin{array}{c}\mathrm{UO}_{2} \\
" \prime\end{array}$ & $\begin{array}{r}\text { AA } \\
\text { TTA }\end{array}$ & $\begin{array}{c}\text { AA } \\
\text { Benzene }\end{array}$ & $\mathrm{pH}=6.5$ & $\mathrm{EDTA}$ を用いると効果的, $\mathrm{Bi}$ および $\mathrm{Pb}$ と分離 & $\begin{array}{l}37) \\
38)\end{array}$ \\
\hline $\mathbf{v}$ & A A & Chloroform & $\mathrm{pH}=2$ & 鉄鋼中の分析 & 39) \\
\hline $\mathbf{Z r}$ & TTA & Xylene & $2 \mathrm{M} \mathrm{HNO}_{3}(\mathrm{HCl})$ & fission products および Hf より分離 & 40), 41) \\
\hline $\mathrm{Zr} \cdot \mathrm{Hf}$ & TTA & Benzene & $2 M \mathrm{HClO}_{4}$ & 両者の精製 & 23) \\
\hline " & TTA & Benzene & $0.2 \mathrm{~N} \mathrm{HCl}$ & & 24) \\
\hline
\end{tabular}

で抽出される. 一方 $\mathrm{Cu}, \mathrm{W}$ および $\mathrm{Cr}$ のような $\mathrm{Mo}$ の比色定量に妨害となる金属はこの酸性では抽出されな い.

\subsection{4 金属の溶媒抽出の一臨表溶媒抽出の応用} 它 Table 6 にまとめた.

\section{6 イン蔽作用}

EDTA 穵用いる金属イオンの電位差滴定においては その選択性が少ない．との妨害金属イオンをキレート生 成試薬によってイン蔽することができる．この場合 $\beta$ ジケトンを用いて $\mathrm{Al}$ や U をイン蔽し，他の金属を EDTA で滴定する. その例としては A1 の共存下の希 土類の滴定で, AA を加えて行うと Al の妨害をのぞく ことができる、しかし Th， Fe および $\mathrm{Zr}$ のイン蔽は 不完全である ${ }^{42) . ~}$

\section{7 脂肪属第一級アミンの定量}

第二，第三級アミンの共存下において，第一級アミン を AA を用いて定量することができる43).すなわち， 脂肪属第一級アミンは一定過剩量の A A と反応してイ そンを生ずる.この過剩の A A をチモールフタレイン を指示薬としてナトリウムメチラートのピリジン溶液で
滴定を行う. 本法は他のアミンによる妨害をふせぐこと ができる. 第一級アルコールアミン,エチレンジアミン,

$$
\begin{array}{cl}
\mathrm{CH}_{3}-\mathrm{C}-\mathrm{CH} & \underset{\text { II }}{\mathrm{C}}-\mathrm{CH}_{3}+\mathrm{R}-\mathrm{NH}_{2} \\
\mathrm{O} & \text { O }
\end{array}
$$

$$
\begin{gathered}
=\mathrm{CH}_{3}-\mathrm{C}-\mathrm{CH}=\mathrm{C}-\mathrm{CH}_{3}+\mathrm{H}_{2} \mathrm{O} \\
\text { N-R OH }
\end{gathered}
$$

アミノ酸, 脂肪属アミンおよびアンモニアの定量が可能 であり, $0.1 \%$ 以内の正確性をもっている.

\section{$8 \beta$-ジケトンの合成法}

$\beta$-ジケトンの合成法は種種あるが，もっとも一般的な 方法はつぎの二つである.

その一つは Claisen 縮合である44).すなわちカルボ ン酸のエステルとケトンとの縮合である.ナトリウム, ナトリウムアルコラートまたはナトリウムアミドなどを 縮合戍として用いる.

$$
\begin{aligned}
& \mathrm{R}-\mathrm{CO}-\mathrm{CH}_{3}+\mathrm{R}^{\prime}-\mathrm{COOC}_{2} \mathrm{H}_{5} \\
& \stackrel{\mathrm{Na}}{\longrightarrow} \mathrm{R}-\mathrm{CO}-\mathrm{CH}_{2}-\mathrm{CO}-\mathrm{R}^{\prime}+\mathrm{C}_{2} \mathrm{H}_{5} \mathrm{OH}
\end{aligned}
$$

フッ素を含有しているものはつぎのとおりである45). 


$$
\begin{aligned}
& \stackrel{\|}{\|}-\mathrm{CO}-\mathrm{CH}_{3}+\mathrm{CF}_{3}-\mathrm{COOC}_{2} \mathrm{H}_{5} \\
& \stackrel{\mathrm{Na}}{\longrightarrow} \underset{\mathrm{S}}{\longrightarrow}-\mathrm{COCH}_{2} \mathrm{COCF}_{3}+\mathrm{C}_{2} \mathrm{H}_{5} \mathrm{OH}
\end{aligned}
$$

他の方法はつぎのとおりである ${ }^{46)}$.

$$
\begin{aligned}
& \mathrm{R}-\mathrm{CHO}+\mathrm{CH}_{3} \mathrm{CO}-\mathrm{R}^{\prime} \stackrel{\mathrm{KOH}}{\longrightarrow} \mathrm{R}-\mathrm{CH}=\mathrm{CH}-\mathrm{CO}-\mathrm{R}^{\prime} \stackrel{\mathrm{Br}_{2}}{\longrightarrow} \\
& \mathrm{R}-\mathrm{CHBr}-\mathrm{CHBr}-\mathrm{CO}-\mathrm{R}^{\prime} \underset{(-\mathrm{HBr})}{\stackrel{\mathrm{KOH}}{\longrightarrow}} \mathrm{R}-\mathrm{C} \equiv \mathrm{C}-\mathrm{CO}-\mathrm{R}^{\prime} \stackrel{\mathrm{H}_{2} \mathrm{O}}{\longrightarrow} \\
& \mathrm{R}-\mathrm{CO}-\mathrm{CH}_{2}-\mathrm{CO}-\mathrm{R}^{\prime}
\end{aligned}
$$

この場合は Claisen 縮合の困難なニトロジベンゾィ ルメタンの合成に便利である.

$$
9 \text { むすび }
$$

本原稿を書いている間に入手した雑誌に分析試薬とし て $\beta$-ジケトンを用いているものを二，三見受けるほど， $\beta$-ジケトンは最近比較的クローズアップされてきてい る. 将来な打多くの $\beta$-ジケトンが合成され，分析の分 野に広く使われるようになると思われる。

本稿は紙数の都合上，充分意を尽せないうらみはある が，分析の新しい分野に少しでも役に立てば幸いと思 う.

\section{文献}

1) F. J. Welcher : “Organic Analytical Reagents" I, 391 (1948).

2) E. Kurorskii : Ber., 43, 1079 (1910).

3）石館守三, 山根靖弘, 玉野田鶴子：本誌，7，170 (1958).

4) R. T. McIntyre, E. W. Berg, D. N. Campbell: Anal. Chem., 28, 1316 (1956).

5) E. W. Berg, J. E. Strassner : ibid, 27, 1131 (1955).

6) F. H. Pollard et al. : J. Chem. Soc., 1951, 466.

7) F. H. Burstall, G. R. Davies, R. P. Linstead, R. A. Wells : ibid., 1950, 516.

8) E. W. Berg, J. E. Strassner : Anal. Chem., 27, 127 (1955).

9) F. H. Pollard, J. F. W. McOmie, I. I. Elbeih: J. Chem. Soc., 1951, 471.

10) F. H. Pollard, H. M. Steven : ibid., 1951, 771.

11) F. H. Pollard, H. M. Steven : ibid., 1951, 1863.

12) E. W. Berg, R. T. McIntyre : Anal. Chem., 26, 813 (1954).

13) E. W. Berg, R. T. McIntyre : ibid., 27, 195 (1955).

14) H. B. Pulsifer : J. Am. Chem. Soc., 26, 967
(1904).

15) P. Wenger, R. Duckert : Helv. Chim. Acta., 27, 757 (1944).

16) W. D. Armstrong: Ind. Eng. Chem., Anal. Ed., 5, 300 (1933).

17) L. V. Milcox : ibid., 6, 167 (1934).

18) J. H. Joe, F. Will, R. A. Black : Anal. Chem., 25, 1200 (1953).

19) C. A. Francois : Anal. Chem., 30, 50 (1958).

20) 原 正:日化, 78, 333，337 (1957).

21）山根靖弘: 薬誌, 77, 400 (1957).

22) F. Hagemann: J. Am. Chem. Soc., 72, 768 (1952).

23) E. H. Haffman, L. J. Beautifait : ibid., 71, 3179 (1949).

24) B. G. Schultz, E. M. Larsen : ibid., 72, 3610 (1950).

25) J. P. McKaveney, H. Freiser : Anal. Chem., 29, 290 (1957).

26) R. A. Boloney, L. Wish : J. Am. Chem. Soc., 72, 4483 (1950).

27) J. F. Steinbach, H. Freiser : Anal. Chem., 26, 375 (1954).

28) T. Y. Toribara, P. S. Chen, Jr : ibid., 24, 539 (1952).

29) G. W. Smith, F. L. Moore : ibid., 29, 448 (1957).

30) J.C. Sullivan, J. C. Hindman : J. Am. Chem. Soc., 76, 5931 (1954).

31) F. L. Moore : Anal. Chem., 29, 941 (1957).

32) F. L. Moore, J. E. Hudgens, Jr : ibid., 29, 1767 (1957).

33) C. Feldman, J. Y. Ellenburg : ibid., 30, 419 (1958).

34) W. W. Meinke, R. E. Anderson : ibid., 24, 708 (1952).

35) R. W. Parkins, D. R. Kalkworf : ibid., 28, 1989 (1956).

36) O. Meis, D. L. Manning, G. Goldstein : ibid., 29, 1427 (1957).

37) A. Krishen, H. Freiser : ibid., 29, 288(1957).

38) R. A. Day, Jr, R. M. Powers : J. Am. Chem. Soc., 76, 3895 (1954).

39) J. P. McKaveney, H. Freiser : Anal. Chem., 30, 526 (1958).

40) F. L. Moore : ibid., 28, 997 (1956).

41) R. E. Connik, W. H. McVey : J. Am. Chem. Soc., 71, 3182 (1949).

42) J. Fritz, M. J. Richard, S. K. Karraker : Anal. Chem., 30, 1347 (1958).

43) F. E. Critchfield, J. B. Johnson : ibid., 29, 1174 (1957).

44) L. Claisen : Ann., 291, 51 (1896).

45) L. B. Barkley, R. Levine : J. Am. Chem. Soc., 73, 4625 (1951).

46) R. P. Banes : ibid., 65, 1583 (1943).

47) J. F. Steinbach, H. Freiser : Anal. Chem., 25, 881 (1953). 